\title{
A Classification of the Nature of Mortality Data Underlying the Estimates for the 2004 and 2006 United Nations' World Population Prospects
}

\author{
Marc Luy
}

\begin{abstract}
The estimation of mortality conditions and trends is a sophisticated task for most populations in the world, above all for those of developing countries. After two decades of intensive discussion and derivation of specific estimation tools for these populations, the use of indirect estimation techniques seems largely forgotten among those who are not forced to apply them. However, for the majority of developing countries these methods are still the main and often the only available estimation tool. In order to systematise the available data and applied estimation techniques, we developed a five-scale classification of the nature of mortality data and assigned all countries with more than 100,000 inhabitants to the corresponding groups. The classification is based on three sources of information regarding the nature of mortality data, the analytical reports of the 2004 and 2006 revisions of the United Nations' World Population Prospects and the methods and data descriptions of the 2006 Global Burden of Disease Study. Although the information provided by our classification is purely descriptive rather than giving a detailed overview of the specific methods and approaches, the contents of this paper should be of interest to politicians and scientists using the United Nations' World Population Prospects as well as to scholars who teach and learn about indirect demographic estimation techniques.
\end{abstract}

Keywords: mortality · nature of mortality data · life expectancy · indirect estimation techniques $\cdot$ model life tables $\cdot$ world population prospects $\cdot$ orphanhood method $\cdot$ growth balance method

\section{Introduction}

The biennially updated "World Population Prospects" (WPP) of the United Nations form probably the most extensively used source of worldwide demographic data. This is well justified since the WPP provide a huge range of demographic indicators 
for current, former and expected future trends for every single country. Moreover, the WPP are prepared very carefully by using the best data available. The existence of such a comprehensive data source may easily conceal the fact that the estimation of demographic conditions and trends is a problematic and sophisticating task for most populations in the world, above all for those of developing countries. Most demographers and population researchers are merely used to the classical direct methods, which are based on sex- and age-specific counts of events like births or deaths and of the living population at risk. In most developing countries, however, such data are either lacking or severely deficient to an extent that the common direct methods cannot be applied.

Mainly during the 1970s and 1980s, demographers developed a number of specific estimation methods to overcome these data problems. These specific estimation tools fall into two major categories: consistency checks with corresponding adjustment methods and indirect estimation techniques. The first group comprises methods which are used for checking the completeness of registered data and for adjusting for typical underreporting in order to obtain less biased demographic measures. In the field of mortality research, the most commonly used consistency checks/adjustment methods are different variants of the growth balance method (Brass 1975; Martin 1980; Gray 1986; Hill 1987; Bhat 2002; Hill/Queiroz 2004) and the inter-census estimation techniques (e.g. Preston/Bennett 1983). With indirect techniques, mortality estimates are derived from survey information on the survival experiences of close relatives or household members. For the estimation of infant and child mortality, the most frequent method is based on information about children ever born and children surviving (Sullivan 1972, Brass 1975, Trussell 1975, Preston/ Palloni 1977, Hill et al. 1983, Hill 1991), whereas the most prominent indirect method for the estimation of adult mortality is the orphanhood method, which is based on survey reports on parental survival. Different approaches have been suggested to convert the share of people with mother or father alive into life table survivorship ratios (Hill/Trussel/ 1977, Hill et al. 1983, Chackiel/Orellana 1985, Timæus 1991a/b, 1992, Timæus/Nunn 1997) or to use two sets of orphanhood data to estimate adult mortality for the time between the surveys (Zlotnik/Hill 1981, Timæus 1986). Other approaches for the indirect estimation of adult mortality are based on the survival of spouses (Hill/Trussell 1977) and siblings (Hill/Trussell 1977, Gakidou/King 2006, Obermeyer et al. 2010). Model life tables - like those by Coale and Demeny (Coale) Demeny 1966, Coale et al. 1983), the United Nations (United Nations 1982a/b) or the INDEPTH network (Ngom/Bawah 2004) - are used to translate survival estimates for specific age segments derived from such indirect techniques into complete life tables and thus into life expectancy.

After two decades of intensive discussion and derivation of these specific estimation tools, the use of consistency checks/adjustment methods and indirect estimation techniques seems largely forgotten among those who are not forced to apply them. However, for the majority of developing countries these methods are still the main and often the only possible estimation tool, even for the most recent demographic data. This paper deals with the methods used by the United Nations to estimate life tables and thus life expectancy for their WPP. Since the final estimates 
are published in one table for all countries, it might seem that the numbers were directly comparable. The different nature of the underlying data and estimation methods, however, should be kept in mind before proceeding with too detailed interpretations. For the three most recent WPP, i.e. the 2004, 2006 and 2008 revisions, the United Nations published some brief information on the available data sources and the applied methods underlying the estimates of current and former conditions, which build the base of the projected future trends. In order to systematise the available data sources and applied estimation techniques, we developed a five-scale classification of the nature of mortality data and assigned all countries into the corresponding groups. Note that the nature of mortality data does not necessarily reflect the accuracy of the data itself, although indirect estimates always include more uncertainties than direct estimates. Since in a number of cases the information provided on the used data and methods is rather vague, our classification contains some uncertainties as well. Furthermore, the information provided in this report is not comparable to the extensive publication of Lopez et al. (2002) who supplied a detailed overview of the specific data sources and methods used for constructing life tables for 191 WHO member states referring to the situation in the late 1990s. As will be shown in the present paper, developing countries most recently experience considerable improvements in the quality of the available mortality data.

\section{A classification of the nature of mortality data}

The creation of a classification of the nature of mortality data has been inspired by similar works of Lopez et al. (2006) and Wilmoth (2007) who both described five categories of data availability but confined their work to a general description rather than providing the corresponding classification for each country. The criteria used for assigning countries to one of these groups differ slightly from one another and also from the criteria we used, and as such, the classification presented in this paper differs from both as well. Our classification is based on three major sources on information regarding the nature of mortality data, the analytical reports of the 2004 and 2006 revisions of United Nations' WPP (United Nations 2006, 2008) and the methods and data descriptions of the "Global Burden of Disease" (GBD) (Lopez et al. 2006). The 2008 revision of United Nations' WPP (United Nations 2010) has not been used because of lacking comparability to the GBD classification as will be discussed in more detail in the concluding remarks. Both the WPP and the GBD provide some - though differently structured - information on data sources and methods underlying the corresponding mortality estimates. Unfortunately, the two sources cannot be matched directly since the GBD published some of the information only for groups of countries following from the classification system of the World Health Organisation (WHO) which differs from the corresponding regional classification system of the United Nations. However, since Lopez et al. (2006) estimated their own life tables for the most part independently from those of the United Nations, the GBD was considered a useful tool for checking our interpretation of the partly vague information provided by the United Nations. 
Our five-group classification is based on the following criteria:

- Group I contains countries with complete and reliable vital registration based on census data. The age- and sex-specific mortality rates as a basis for the life tables are calculated directly and unadjusted from the officially registered data.

- Group II contains countries for which the calculation or derivation of ageand sex-specific death rates is still possible. However, some adjustments of the registered data or the use of additional data sources are necessary. This group contains countries of three kinds of data characteristics: (i) countries whose vital registration and census data show some deficiencies making adjustments of the numbers of deaths or the living population necessary, (ii) countries with current death registration in which former census data or life tables allow to derive estimates for the current age and sex composition of the living population from specific projection or modelling, and (iii) countries with existing death registers but whose data on infant and/or child mortality are based on other data sources, i.e. indirect estimates from survey or census data.

- Group III contains countries whose life tables are not based on age- and sexspecific death rates but on two separated estimates, one for child mortality and one for a global level of adult mortality. Estimates of child mortality are based on data from registers, censuses, DHS and PAPCHILD surveys or surveillance systems. Regarding the estimation of adult mortality levels, the countries assigned to this group fall into two broad categories: (i) countries whose estimates for adult mortality are based on former life tables dating back too far to derive current age- and sex-specific death rates by projection techniques but allow deriving estimates for a global level of adult mortality, and (ii) countries with estimates of adult mortality levels from indirect estimation techniques based on information about surviving parents or siblings from survey data. In most countries of this group, the final estimates for life expectancy are derived from model life table systems or are adopted from alternative sources like WHO or ESCWA estimates.

- Group IV contains countries whose estimates for life expectancy are solely based on direct or indirect estimates of child mortality, using model life table systems for the derivation of the corresponding life table for the total population. As in group III, estimates of child mortality are based on data from registers, censuses, DHS and PAPCHILD surveys or surveillance systems. In some cases, UNICEF and WHO estimates were considered as well.

- Group V contains countries without any useful information on prevailing mortality conditions. In these cases, the estimated life expectancy is assumed to be similar to those of neighbouring countries with comparable socio-economic conditions, usually belonging to group IV.

In practice, classifying countries into groups I or $\mathrm{V}$ was mostly unproblematic. However, the classification of countries into the groups II, III and IV was a sophisticated task given the information provided on the data sources and methods for life table derivation. Nevertheless, using all available information from the WPP 2004 and WPP 2006 analytical reports and the GBD, we kept our classification criteria as clearly as possible. First, we classified the countries for the WPP 2004 since the years of data collection are roughly the same as for the GBD and therefore the information from the two sources could be combined. Our final classification of 
countries into the five groups for the WPP 2004 is mostly consistent with the analytical reports of the United Nations (2006) and very close to the GBD classification. The classification for the WPP 2006 is based on the analytical reports of the United Nations (2008) and on our own classification for the WPP 2004. Note that since both the WPP analytical reports and the GBD description are used for assigning countries into the groups of nature of mortality data, some classifications might not correspond to the description of one report on its own. Some examples might help explaining the difficulties for, and the logic behind, our classification.

For the majority of the African countries the WPP analytical reports describe the source for life expectancy estimates as "derived from estimates on infant and child mortality by assuming that the age pattern of mortality conforms to the [...] model of the [...] Model Life Tables". In most cases this statement is supplemented by "the demographic impact of AIDS has been factored into the mortality estimates". In cases where no further information is given other than that the estimates are based on infant and child mortality, countries were assigned to group IV. For some countries like Bhutan, the WPP analytical report additionally included the information that some older (official) life table estimates were considered. However, it remains unclear if these additional sources were used for estimating adult mortality levels or if they were used to test and adjust the estimates for child mortality. For classifying such countries we incorporated the information from the GBD, where for the main WHO regions the number of countries is listed by their five classes of mortality data. If the GBD classification indicates that the country should belong to group III we assigned this country to group III as well.

For other countries the data description of the WPP 2004 analytical report leaves open whether they belong to group II or to group III. If the GBD team could not reconstruct age-and sex-specific rates from the data of such countries, they were assigned to group III, as long as the WPP 2004 analytical report did not contain any explicit remark on age- and sex-specific data availability. Consequently, when the description in the WPP 2006 analytical report did not change, the country remained in data quality group III, although the analytical report itself might indicate mortality data of quality group II. Algeria is an example for such a classification.

Furthermore, there are other countries theoretically fulfilling the criteria for group II (or even group I) but where the final estimates of the United Nations are based on model life tables. Such countries were classified into group III, since obviously the data quality is insufficient to derive age- and sex-specific death rates. Tunisia is such a country; it has regular censuses and official estimates for infant and child mortality as well as for life expectancy provided by INS Tunisia (see also Vallin/ Locoh 2001). However, the life expectancy in Tunisia reported in the WPP is based on an underlying age pattern of mortality that conforms to the East model of the Coale-Demeny model life table system. Bolivia and South Africa are further examples of countries where the theoretically available data contradict our classification. In Bolivia, the national statistical office publishes official life tables while the United Nations based their estimates for the WPP on indirect estimations. The same holds for South Africa, where works of local demographers suggest that the available data could provide adjusted age- and sex-specific death rates and that the application of 
model life tables might not be necessary (Dorrington et al. 2006). However, since the United Nations choose the data for their WPP very carefully, there seem to be justified reservations with regard to the quality of such sources.

Finally, there are countries such as Morocco, for which, according to the WPP analytical reports, no information on adult mortality exist. However, regarding the trend of the age pattern of mortality the United Nations assumed for the WPP 2006 a convergence from the South to the East level of the Coale-Demeny model life tables, whereas all former, current and future estimates of the WPP 2004 were based solely on the West level. This indicates that at least some information on adult mortality patterns must have been available, and thus, Morocco has been classified into group III. Furthermore, classifying Morocco into group III was necessary in order to create figures in accordance with the GBD classification for countries of the WHO region 'Middle East and North Africa'.

\section{A worldwide overview of the nature of mortality data}

The distribution of countries with more than 100,000 inhabitants into the five groups of nature of mortality data underlying the WPP 2004 and WPP 2006 is shown in tables 1 and 2 for the world's major areas, as well as in figures 1 and 2 for each country. Furthermore, the country-specific classification for the WPP 2004 and the WPP 2006 and the model life table systems used for the WPP 2006 can be found in the appendix of this paper. Table 1 shows that for the life expectancy estimates of the United Nations' WPP 2004 the countries are almost evenly distributed among groups I-IV. There are only two countries without any data on mortality, Western Sahara and Guinea-Bissau. The group to which most countries are assigned to is group IV with 52 countries. 42 of these countries are from Africa, seven from Asia, two from Latin America and one from Oceania. Group III contains 42 countries, dominated by 18 from Asia. The other 24 countries of this group are distributed evenly across Africa, Oceania, and Latin America and the Caribbean. Group II consisting of 47 countries mainly comprises countries from Latin America and the Caribbean (21) and Asia (16). Further, eight European countries and one country from each Africa and Oceania also belong to this group. The group with the highest quality of mortality data contains 49 countries out of which most are from Europe (31) but also from Asia (9), Latin America and the Caribbean, furthermore from the United States and Canada, Australia and New Zealand as well as Mauritius (see also Fig. 1).

A comparison between the WPP 2004 and WPP 2006 reveals some dynamics in the nature of mortality data underlying the most recent life expectancy estimates, mainly in terms of having more detailed data available (see Tab. 1 and Tab. 2). The most significant changes are shifts from group IV to group III which mainly occurred in western African countries (Burkina Faso, Gambia, Mali, Mauritania, Niger and Senegal), but also in São Tomé and Príncipe, Libya, South Africa, Bhutan, Iran, Saudi Arabia, Yemen, and Saint Vincent and the Grenadines. Three countries moved in our classification from group III to group II, the Democratic People's Republic of Korea, Sri Lanka and Kuwait. However, according to the analytical reports of WPP 2004 and 
Tab. 1: Classification of the nature of mortality data underlying the estimation of life expectancy in United Nations' World Population Prospects 2004 for the world's major areas

\begin{tabular}{lrrrrr}
\hline & \multicolumn{5}{c}{ Group of nature of mortality data } \\
& I & II & III & IV & V \\
\hline WORLD & 49 & 47 & 42 & 52 & 2 \\
Africa & 1 & 1 & 8 & 42 & 2 \\
Asia & 9 & 16 & 18 & 7 & 0 \\
Europe & 31 & 8 & 0 & 0 & 0 \\
Latin America and the Caribbean & 4 & 21 & 8 & 2 & 0 \\
Northern America & 2 & 0 & 0 & 0 & 0 \\
Oceania & 2 & 1 & 8 & 1 & 0 \\
\hline
\end{tabular}

Source: own reconstruction based on information provided by the United Nations (2006) and Lopez et al. (2006)

Fig. 1: Classification of the nature of mortality data underlying the estimation of life expectancy in United Nations' World Population Prospects 2004
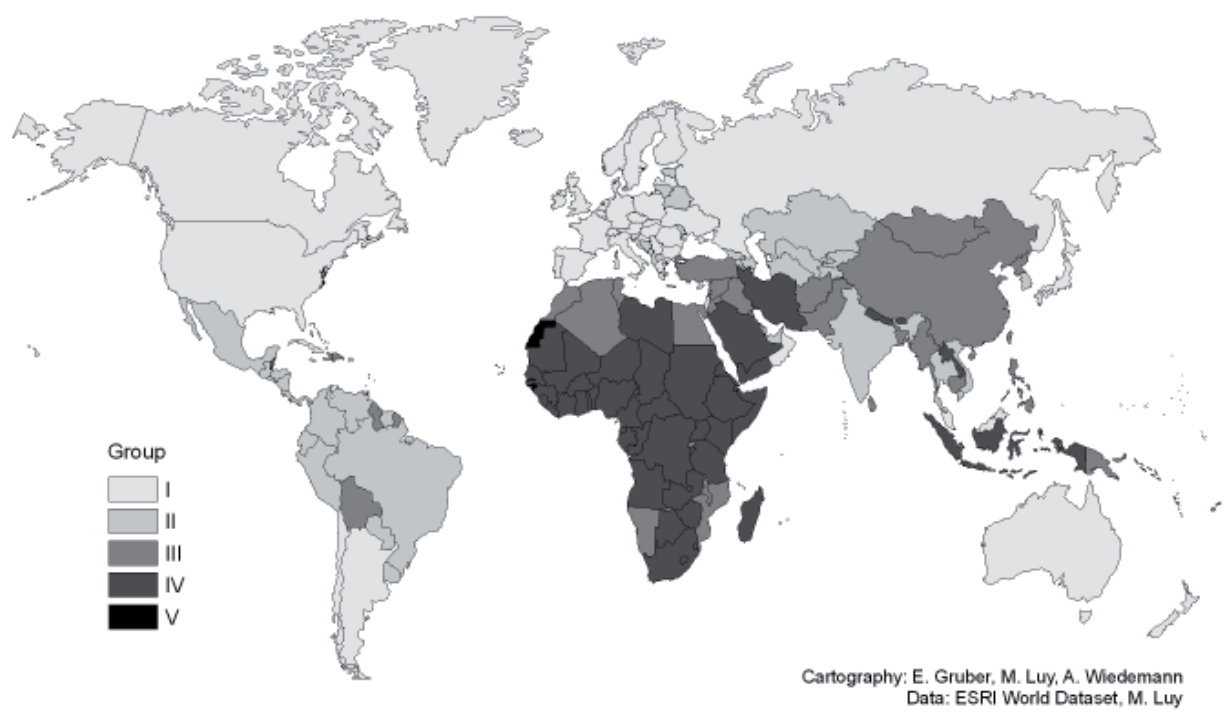

Data: own reconstruction based on information provided by the United Nations (2006) and Lopez et al. (2006)

WPP 2006, there are also shifts in the other direction. Two countries changed from group I to group II (Bahrain and Ukraine), one from group II to group III (Maldives) and another one from group III to group IV (Lebanon). These shifts towards less detailed and less accurate mortality data are based on the WPP analytical reports. 
Tab. 2: Classification of the nature of mortality data underlying the estimation of life expectancy in United Nations' World Population Prospects 2006 for the world's major areas

\begin{tabular}{lrrrrr}
\hline & \multicolumn{5}{c}{ Group of nature of mortality data } \\
& \multicolumn{1}{c}{ I } & II & III & IV & V \\
\hline WORLD & 47 & 51 & 53 & 39 & 2 \\
Africa & 1 & 1 & 17 & 33 & 2 \\
Asia & 8 & 19 & 19 & 4 & 0 \\
Europe & 30 & 9 & 0 & 0 & 0 \\
Latin America and the Caribbean & 4 & 21 & 9 & 1 & 0 \\
Northern America & 2 & 0 & 0 & 0 & 0 \\
Oceania & 2 & 1 & 8 & 1 & 0 \\
\hline
\end{tabular}

Source: own reconstruction based on information provided by the United Nations (2006, 2008) and Lopez et al. (2006)

Fig. 2: Classification of the nature of mortality data underlying the estimation of life expectancy in United Nations' World Population Prospects 2006

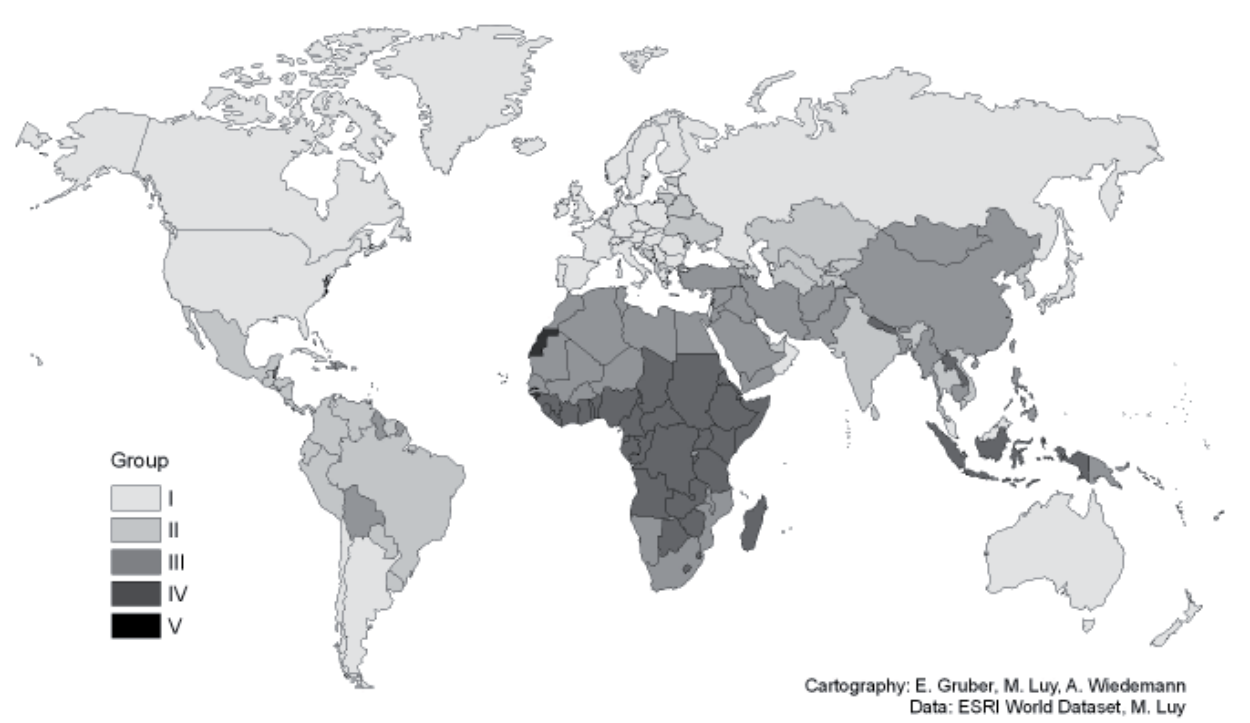

Data: own reconstruction based on information provided by the United Nations (2006, 2008) and Lopez et al. (2006)

In Bahrain, for instance, adjustments had to be made for infant and child mortality for the WPP 2006, which was not necessary according to the WPP 2004 analytical report. The Maldives changed from group II to group III because the estimates for life expectancy of the WPP 2004 had been based on official estimates, whereas the 
WPP 2006 estimates used Coale-Demeny model life tables. In sum, regarding the nature of mortality data underlying the life expectancy estimates of the WPP 2006, most countries belong to group III (53), followed by group II (51), group I (47) and group IV (39). No improvements took place in Western Sahara and Guinea-Bissau, so both countries still belong to group V for the WPP 2006 estimates as they already did for the WPP 2004 (see also Fig. 2).

Looking at the distribution of countries into the five groups of nature of mortality data for the world's major areas reveals that most African countries belong to group IV, despite the remarkable shifts to group III. Most Asian countries belong to the groups II and III, although there are still four countries belonging to group IV (Lebanon, Nepal, Indonesia and Laos). Most European countries produce more detailed and more accurate mortality data. However, there are still nine countries from eastern and south-eastern Europe where an adjustment of age- and sex-specific death rates is necessary (Belarus, Moldova, Ukraine, Estonia, Lithuania, Albania, Bosnia and Herzegovina, Malta, TFYR Macedonia). Most countries from Latin America and the Caribbean belong to group II, nine to group III, four to group I (Argentina, Chile, Cuba, Netherlands Antilles), and with Belize one to group IV. Apart from Australia and New Zealand, most countries from Oceania belong to group III. There is only one country each in group II (French Polynesia) and group IV (Federal States of Micronesia).

Regarding the groups of nature of mortality data of the WPP 2006, it has already been said that group I contains developed high-income countries from Europe, America and Asia (see Tab. 2 and Fig. 2). Most of the 51 countries belonging to group II are from Latin America and the Caribbean (21) and Asia (19), complemented by the nine European countries mentioned above as well as Réunion and French Polynesia from Africa and Oceania, respectively. The 53 countries of group III are mainly countries from Asia (19) and Africa (17), complemented by nine from Latin America and the Caribbean and eight from Oceania. With 33 out of 39 countries, Africa dominates group IV. The other six countries of this group are Lebanon, Nepal, Indonesia, Laos (Asia), Belize (Latin America and the Caribbean) and the Federal States of Micronesia (Oceania).

Finally, we looked at the specific estimation tools that were used for estimates of life expectancy of the WPP 2006 in cases where the available mortality data was insufficient to produce direct age- and sex-specific death rates. In most cases, the indirect estimates of infant and child mortality are based on the number of children ever born and children surviving obtained from survey or census information, or from maternity history and the number of births during the twelve preceding months from the same sources of information. Regarding the estimation of adult mortality, the orphanhood method was explicitly mentioned in 13 cases (Burkina Faso, Gambia, Mali, Mauritania, Niger, Senegal, Dominican Republic, Bolivia, Papua New Guinea, Solomon Island, Vanuatu, Samoa, Tonga), the growth balance method and its variants were given ten times (Haiti, El Salvador, Honduras, Panama, Brazil, Colombia, Ecuador, Paraguay, Peru, Venezuela). At least for the latter, the number of applications is probably higher since in most cases the only information was that some adjustment had been done without any specification of the used method. 
In order to overcome the lack of data in modelling life tables on some information about child - and in some cases additionally on adult - mortality levels, for 79 out of the 92 countries belonging to quality groups III and IV model life tables were used (see Appendix). The most commonly used model life tables are those from the Coale-Demeny model life table system, in particular the West pattern. The CoaleDemeny West pattern provides the background for 27 life table estimates, whereas the North pattern was used for 20, the South pattern for eight and the East pattern for six country estimates. For twelve countries, the United Nations model life table system was applied, dominated by the Far Eastern pattern which was used for the estimates for nine countries, while the Latin American, the South Asian and the General pattern each were used once. For six countries in western Africa (Burkina Faso, Gambia, Mali, Mauritania, Niger, Senegal) the traditional Coale-Demeny model life table system was replaced by Pattern 1 from the recently published INDEPTH model life tables.

Interestingly, there are some other cases where the model life table system used was changed between the WPP 2004 and WPP 2006 which also changed the assumed pattern of age-specific mortality indicating the existence of new information regarding former and current mortality trends. The model life tables have been changed for Laos from Coale-Demeny North to Coale-Demeny West, for Barbados, Cambodia and Afghanistan from Coale-Demeny South to Coale-Demeny West, for Tanzania from Coale-Demeny South to Coale-Demeny North, for Chad from CoaleDemeny North to Coale-Demeny South, for Morocco from Coale-Demeny West to Coale-Demeny East, for Belize from UN Latin American to UN General, and finally for the Solomon Islands from UN Far Eastern to Coale-Demeny West.

\section{$4 \quad$ Concluding remarks}

This paper makes an attempt at creating a five-scale classification of nature of mortality data for all countries of the world with more than 100,000 inhabitants, referring to the data and methods used by the United Nations for their WPP, namely the 2004 and 2006 revisions. These are the first two WPP for which at least some information about the specific data and methods is provided by analytical reports. Besides describing the classification criteria we also assessed the worldwide situation of mortality data availability and the changes which occurred between the two WPP. The most important change was the upgrade of many - mainly African - countries from group IV to group III. However, Africa and to some extent south-eastern Asia are still the areas with most incomplete and probably least reliable data about mortality levels and trends. Technically, the major change between WPP 2004 and WPP 2006 is the extension of the model life table systems used to the INDEPTH model life tables, and the use of data from the Human Mortality Database (HMD) instead of material from official sources for some countries from eastern and south-eastern Europe (Bulgaria, Russian Federation, Slovakia, Ukraine).

The most recently published 2008 revision of United Nations' WPP indicates that with regard to the nature and accuracy of mortality data the situation has fur- 
ther improved compared to the WPP 2006. This mainly concerns some African as well as eastern and western Asian regions. On the other side, the most recent life table estimates for the Russian Federation and Ukraine incorporated adjustments to infant mortality, and in those for the U.S. the demographic impact of AIDS has been factored. These adjustments were not done in the estimates of the WPP 2006 according to the corresponding analytical report. In this paper we did not include the WPP 2008 in our analysis since many descriptions in the actual analytical report are too vague for classification and would need additional information. Since there have been some obvious changes compared to the WPP 2004 and WPP 2006, the GBD 2006 is not sufficiently up-to-date. Nevertheless, it is interesting to note that the United Nations stopped using the INDEPTH model life tables for the WPP 2008 life expectancy estimates and substituted them by the Timæus Sahelian mortality pattern (Timæus 1999). Further changes in the used model life table system were made for Sierra Leone (from Coale-Demeny South to the Timæus Western and Eastern Africa mortality pattern), Liberia (from Coale-Demeny West to Coale-Demeny South) and Iraq (from Coale-Demeny East to Coale-Demeny West and the Brass General Standard).

In the final count, the developed classification for the WPP 2004 and WPP 2006 might not be perfectly precise for every country. In particular, the differentiation between groups II and III was difficult in some cases. Furthermore, the classification does not provide a detailed overview of the specific methods and approaches used by the United Nations Population Division. For instance, the new data from the DHS/ RHS/Arab League etc. birth histories have led to the production of a whole new set of figures based on birth history analysis. Detailed insights into the specific methods have been omitted because the intention of this paper was to provide a crude and descriptive overview of the situation of mortality statistics underlying the WPP 2004 and WPP 2006. However, the paper should by no means be understood as criticism on the work of the United Nations Population Division and their estimates and projections of life expectancy. The lack of data in most developing countries is not the fault of the United Nations and their efforts in producing the most reliable estimates of life expectancy deserve high credit. Above all the United Nations Population Division's work factoring the demographic impact of AIDS is particularly difficult and very well done.

Likewise, the goal of this overview was neither to discuss the processes or mechanisms by which countries moved up in the classification, nor to provide a detailed assessment of the state of vital registration in each country. This would require a careful analysis and much more extensive literature research for each country. Nevertheless, the contents of this paper should be of interest for politicians and scientists using the United Nations WPP as well as for scholars who teach and learn about indirect demographic estimation techniques. For the latter, it is especially interesting to see in which countries these methods are still applied, in order to realise the important role which indirect methods and model life tables still play in recent demographic estimates of the world.

The author thanks Werner Richter and Barbara Müller for language editing. 


\section{References}

Bhat, P.N. Mari, 2002: General growth balance method: a reformulation for populations open to migration. In: Population Studies 56,1: 23-34

Brass, William, 1975: Methods for estimating fertility and mortality from limited and defective data. Chapel Hill: University of North Carolina

Chackiel, Juan; Orellana, Hernán, 1985: Adult female mortality trends from retrospective questions about maternal orphanhood included in censuses and surveys. In: International Union for the Scientific Study of Population (ed.): IUSSP International Population Conference, Florence 1985, 4. Liège: IUSSP: 39-51

Coale, Ansley J.; Demeny, Paul, 1966: Regional model life tables and stable populations. Princeton: Princeton University Press

Coale, Ansley J.; Demeny, Paul; Vaughan, Barbara, 1983: Regional model life tables and stable populations. Second edition. New York et al.: Academic Press

Dorrington, Rob; Timæus lan M.; Gregson, Simon, 2006: Adult mortality in southern Africa using deaths reported by households: some methodological issues and results. Paper presented at the PAA 2006 Annual Meeting. Los Angeles, March 2006

Gakidou, Emmanuela; King, Gary, 2006: Death by survey: estimating adult mortality without selection bias from sibling survival data. In: Demography 43,3: 569-585

Gray, Alan, 1986: Sectional growth balance analysis for non-stable closed populations. In: Population Studies 40,3: 425-436

Hill, Kenneth, 1987: Estimating census and death registration completeness. In: Asian and Pacific Population Forum 1,3: 8-13

Hill, Kenneth, 1991: Approaches to the measurement of childhood mortality: a comparative review. In: Population Index 57,3: 368-382

Hill, Kenneth; Queiroz, Bernardo, 2004: Adjusting general growth balance method for migration. Paper presented at the AMDC Meeting. Berkley, July 2004

Hill, Kenneth; Trussell, James, 1977: Further developments in indirect mortality estimation. In: Population Studies 31,2: 313-334

Hill, Kenneth; Zlotnik, Hania; Trussell, James, 1983: Manual X: Indirect techniques for demographic estimation. New York: United Nations

Lopez, Alan D.; Ahmad, Omar B.; Guillot, Michel; Ferguson, Brodie D.; Salomon, Joshua A.; Murray, Christopher J.L.; Hill, Kenneth, 2002: World mortality in 2000: life tables for 191 countries. Geneva: WHO

Lopez, Alan D.; Mathers, Colin D.; Ezzati, Majid; Jamison, Dean T.; Murray, Christopher J.L., 2006: Global burden of disease and risk factors. New York: Oxford University Press, World Bank

Martin, Linda G., 1980: A modification for use in destabilized populations of Brass's technique for estimating completeness of death registration. In: Population Studies 34,2: 381-395

Ngom, Pierre; Bawah, Ayaga A., 2004: INDEPTH model life tables for Sub-Saharan Africa. Aldershot/Burlington: Ashgate

Obermeyer, Ziad; Rajaratnam, Julie Knoll; Park, Chang H.; Gakidou, Emmanuela; Hogan, Margaret C.; Lopez, Alan D.; Murray, Christopher J. L., 2010: Measuring adult mortality using sibling survival: a new analytical method and new results for 44 countries, 1974-2006. In: PLOS Medicine 7,4: e1000260 
Preston, Samuel H.; Bennett, Neil G., 1983: A census-based method for estimating adult mortality. In: Population Studies 37,1: 91-104

Preston, Samuel H.; Palloni, Alberto, 1977: Fine-tuning Brass-type mortality estimates with data on ages of surviving children. In: Population Bulletin of the United Nations 10-1977: 72-91

Sullivan, Jeremiah M., 1972: Models for the estimation of probabilities of dying between birth and exact ages of early childhood. In: Population Studies 26,1: 79-97

Timæus, lan M., 1986: An assessment of methods for estimating adult mortality from two sets of data on maternal orphanhood. In: Demography 23,3: 435-450

Timæus, Ian M., 1991a: Estimation of adult mortality from orphanhood before and since marriage. In: Population Studies 45,3: 455-472

Timæus, lan M., 1991b: Estimation of adult mortality from orphanhood in adulthood. In: Demography 28,2: 213-227

Timæus, lan M., 1992: Estimation of adult mortality from paternal orphanhood: a reassessment and a new approach. In: Population Bulletin of the United Nations 33: 47-63

Timæus, lan M., 1999: Notes on a series of life table estimates of mortality in the countries of the Sub-Saharan Africa region. Unpublished manuscript prepared for the WHO

Timæus, lan M.; Nunn, Andrew J., 1997: Measurement of adult mortality in populations affected by AIDS: an assessment of the orphanhood method. In: Health Transitions Review 7, Supplement 2: 23-43

Trussell, T. James, 1975: A re-estimation of the multiplying factors for the Brass technique for determining childhood survivorship rates. In: Population Studies 29,1: 97-107

United Nations, 1982a: Model life tables for developing countries. New York: United Nations

United Nations, 1982b: Unabridged model life tables corresponding to the new United Nations model life tables for developing countries. New York: United Nations

United Nations, 2006: World population prospects. The 2004 revision. Volume III: Analytical report. New York: United Nations

United Nations, 2008: World population prospects. The 2006 revision. Volume III: Analytical report. New York: United Nations

United Nations, 2010: World population prospects. The 2008 revision. Volume III: Analytical report. New York: United Nations

Vallin, Jacques; Locoh, Thérèse, 2001: Population et développement en Tunisie. La métamorphose. Tunis: Cérès

Wilmoth, John R., 2007: The duration of life throughout the world. What do we know and how do we know it? Paper presented at the Max Planck Institute for Demographic Research, Rostock, May 2007

Zlotnik, Hania; Hill, Kenneth, 1981: The use of hypothetical cohorts in estimating demographic parameters under conditions of changing fertility and mortality. Demography 18,1: 103-122 
328 - Marc Luy

A German translation of this authorised original article by the author is available under the title "Eine Klassifikation der Mortalitätsdaten für die Schätzungen der United Nations' World Population Prospects 2004 und 2006", DOI 10.4232/10.CPoS-2010-08de or URN urn:nbn:de:bib-cpos2010-08de8, at http://www.comparativepopulationstudies.de.

Dr. Marc Luy $(\bowtie)$. Austrian Academy of Sciences, Vienna Institute of Demography, A-1040 Vienna, Austria.

E-Mail: mail@marcluy.eu 


\section{Appendix}

Classification of the nature of mortality data and used Model Life Table System underlying the data for the estimation of life expectancy in United Nations' World Population Prospects 2004 and 2006 for each country

$2004 \quad 2006$

Model Life Table System

\section{Africa}

\section{Eastern Africa}

\begin{tabular}{|c|c|c|c|}
\hline Burundi & IV & IV & Coale-Demeny North \\
\hline Comoros & IV & IV & Coale-Demeny West \\
\hline Djibouti & IV & IV & Coale-Demeny West \\
\hline Eritrea & IV & IV & UN Far East \\
\hline Ethiopia & IV & IV & Coale-Demeny North \\
\hline Kenya & IV & IV & Coale-Demeny North \\
\hline Madagascar & IV & IV & Coale-Demeny North \\
\hline Malawi & III & III & Coale-Demeny South \\
\hline Mauritius & I & I & ----- \\
\hline Mozambique & III & III & Coale-Demeny North \\
\hline Réunion & II & II & ----- \\
\hline Rwanda & III & III & ----- \\
\hline Somalia & IV & IV & Coale-Demeny North \\
\hline Uganda & IV & IV & Coale-Demeny North \\
\hline United Republic of Tanzania & IV & IV & Coale-Demeny North \\
\hline Zambia & IV & IV & Coale-Demeny North \\
\hline Zimbabwe & IV & IV & Coale-Demeny North \\
\hline \multicolumn{4}{|l|}{ Middle Africa } \\
\hline Angola & IV & IV & Coale-Demeny North \\
\hline Cameroon & IV & IV & Coale-Demeny North \\
\hline Central African Republic & IV & IV & Coale-Demeny North \\
\hline Chad & IV & IV & Coale-Demeny South \\
\hline Congo & IV & IV & Coale-Demeny West \\
\hline Democr. Rep. of the Congo & IV & IV & Coale-Demeny North \\
\hline Equatorial Guinea & IV & IV & Coale-Demeny North \\
\hline Gabon & IV & IV & Coale-Demeny North \\
\hline Sao Tome and Principe & IV & III & Coale-Demeny South \\
\hline \multicolumn{4}{|l|}{ Jorthern Africa } \\
\hline Algeria & III & III & ----- \\
\hline Egypt & III & III & Coale-Demeny East \\
\hline Libyan Arab Jamahiriya & IV & III & UN Far East \\
\hline Morocco & III & III & Coale-Demeny East \\
\hline Sudan & IV & IV & Coale-Demeny North \\
\hline Tunisia & III & III & Coale-Demeny East \\
\hline Western Sahara & V & V & ----- \\
\hline
\end{tabular}




\begin{tabular}{|c|c|c|c|}
\hline & 2004 & 2006 & Model Life Table System \\
\hline \multicolumn{4}{|l|}{ Southern Africa } \\
\hline Botswana & IV & IV & Coale-Demeny West \\
\hline Lesotho & IV & IV & Coale-Demeny West \\
\hline Namibia & III & III & Coale-Demeny West \\
\hline South Africa & IV & III & UN Far East \\
\hline Swaziland & IV & IV & Coale-Demeny West \\
\hline \multicolumn{4}{|l|}{ Western Africa } \\
\hline Benin & IV & IV & Coale-Demeny South \\
\hline Burkina Faso & IV & III & INDEPTH 1 \\
\hline Cape Verde & IV & IV & Coale-Demeny West \\
\hline Côte d'Ivoire & IV & IV & Coale-Demeny South \\
\hline Gambia & IV & III & INDEPTH 1 \\
\hline Ghana & IV & IV & Coale-Demeny North \\
\hline Guinea & IV & IV & Coale-Demeny South \\
\hline Guinea-Bissau & $\mathrm{V}$ & $\mathrm{V}$ & ---- \\
\hline Liberia & IV & IV & Coale-Demeny West \\
\hline Mali & IV & III & INDEPTH 1 \\
\hline Mauritania & IV & III & INDEPTH 1 \\
\hline Niger & IV & III & INDEPTH 1 \\
\hline Nigeria & IV & IV & Coale-Demeny North \\
\hline Senegal & IV & III & INDEPTH 1 \\
\hline Sierra Leone & IV & IV & Coale-Demeny South \\
\hline Togo & IV & IV & Coale-Demeny South \\
\hline \multicolumn{4}{|l|}{ Asia } \\
\hline \multicolumn{4}{|l|}{ Eastern Asia } \\
\hline China & III & III & ----- \\
\hline China, Hong Kong Spec. Adm. R. & I & 1 & ---- \\
\hline China, Macao Spec. Adm. Region & I & I & ---- \\
\hline Democr. People's Rep. of Korea & III & ॥ & ---- \\
\hline Japan & 1 & I & ----- \\
\hline Mongolia & III & III & ----- \\
\hline Republic of Korea & $\|$ & $\|$ & ---- \\
\hline \multicolumn{4}{|l|}{ South-central Asia } \\
\hline Afghanistan & III & III & Coale-Demeny West \\
\hline Bangladesh & III & III & Coale-Demeny West \\
\hline Bhutan & IV & III & Coale-Demeny North \\
\hline India & $\|$ & ॥ & ---- \\
\hline Iran (Islamic Republic of) & IV & III & Coale-Demeny East \\
\hline Kazakhstan & II & II & ---- \\
\hline Kyrgyzstan & II & II & ----- \\
\hline
\end{tabular}




\begin{tabular}{|c|c|c|c|}
\hline & 2004 & 2006 & Model Life Table System \\
\hline Maldives & II & III & Coale-Demeny West \\
\hline Nepal & IV & IV & Coale-Demeny West \\
\hline Pakistan & III & III & UN South Asia \\
\hline Sri Lanka & III & $\|$ & ----- \\
\hline Tajikistan & ॥ & ॥ & ----- \\
\hline Turkmenistan & II & ॥ & ----- \\
\hline Uzbekistan & II & $\|$ & ---- \\
\hline \multicolumn{4}{|l|}{ South-eastern Asia } \\
\hline Brunei Darussalam & II & ॥ & ----- \\
\hline Cambodia & III & III & Coale-Demeny West \\
\hline Democr. Rep. of Timor-Leste & III & III & Coale-Demeny West \\
\hline Indonesia & IV & IV & Coale-Demeny West \\
\hline Lao People's Democratic & & & \\
\hline Republic & IV & IV & Coale-Demeny West \\
\hline Malaysia & 1 & 1 & ---- \\
\hline Myanmar & III & III & UN Latin America \\
\hline Philippines & III & III & ---- \\
\hline Singapore & 1 & 1 & ----- \\
\hline Thailand & II & II & ----- \\
\hline Viet Nam & II & II & ----- \\
\hline \multicolumn{4}{|l|}{ Western Asia } \\
\hline Armenia & II & ॥ & ----- \\
\hline Azerbaijan & II & ॥ & ---- \\
\hline Bahrain & I & ॥ & ---- \\
\hline Cyprus & I & I & ---- \\
\hline Georgia & $\|$ & $\|$ & ---- \\
\hline Iraq & III & III & Coale-Demeny East \\
\hline Israel & I & I & ---- \\
\hline Jordan & III & III & ---- \\
\hline Kuwait & III & ॥ & ---- \\
\hline Lebanon & III & IV & Coale-Demeny West \\
\hline Occupied Palestinian Territory & III & III & ---- \\
\hline Oman & I & I & ---- \\
\hline Qatar & II & II & ---- \\
\hline Saudi Arabia & IV & III & Coale-Demeny West \\
\hline Syrian Arab Republic & III & III & Coale-Demeny West \\
\hline Turkey & III & III & Coale-Demeny East \\
\hline United Arab Emirates & $\|$ & $\|$ & Coale-Demeny West \\
\hline Yemen & IV & III & Coale-Demeny West \\
\hline
\end{tabular}




\begin{tabular}{|c|c|c|c|}
\hline & 2004 & 2006 & Model Life Table System \\
\hline \multicolumn{4}{|l|}{ Europe } \\
\hline \multicolumn{4}{|l|}{ Eastern Europe } \\
\hline Belarus & II & II & ---- \\
\hline Bulgaria & I & 1 & ----- \\
\hline Czech Republic & I & I & ----- \\
\hline Hungary & I & I & ----- \\
\hline Poland & I & I & ---- \\
\hline Republic of Moldova & II & II & ----- \\
\hline Romania & 1 & 1 & ----- \\
\hline Russian Federation & I & I & ----- \\
\hline Slovakia & I & 1 & ----- \\
\hline Ukraine & 1 & II & ----- \\
\hline \multicolumn{4}{|l|}{ Northern Europe } \\
\hline Channel Islands & 1 & I & ---- \\
\hline Denmark & 1 & 1 & ---- \\
\hline Estonia & II & II & ---- \\
\hline Finland & 1 & 1 & ---- \\
\hline Iceland & 1 & 1 & ---- \\
\hline Ireland & I & 1 & ---- \\
\hline Latvia & I & 1 & ---- \\
\hline Lithuania & II & II & ----- \\
\hline Norway & 1 & 1 & ---- \\
\hline Sweden & I & 1 & ----- \\
\hline United Kingdom & I & 1 & ----- \\
\hline \multicolumn{4}{|l|}{ Southern Europe } \\
\hline Albania & II & II & ---- \\
\hline Bosnia and Herzegovina & II & II & ---- \\
\hline Croatia & 1 & 1 & ---- \\
\hline Greece & 1 & 1 & ---- \\
\hline Italy & 1 & 1 & ---- \\
\hline Malta & II & II & ---- \\
\hline Portugal & I & 1 & ---- \\
\hline Serbia and Montenegro & I & I & ---- \\
\hline Slovenia & I & I & ----- \\
\hline Spain & I & I & ----- \\
\hline TFYR Macedonia & II & II & ---- \\
\hline \multicolumn{4}{|l|}{ Western Europe } \\
\hline Austria & 1 & 1 & ---- \\
\hline Belgium & 1 & 1 & ---- \\
\hline France & 1 & 1 & ---- \\
\hline
\end{tabular}




\begin{tabular}{|c|c|c|c|}
\hline & 2004 & 2006 & Model Life Table System \\
\hline Germany & I & I & ----- \\
\hline Luxembourg & I & 1 & ----- \\
\hline Netherlands & I & 1 & ---- \\
\hline Switzerland & I & 1 & ----- \\
\hline \multicolumn{4}{|l|}{ Latin America and the Caribbean } \\
\hline \multicolumn{4}{|l|}{ Caribbean } \\
\hline Bahamas & II & II & ----- \\
\hline Barbados & III & III & Coale-Demeny West \\
\hline Cuba & 1 & I & ----- \\
\hline Dominican Republic & III & III & ----- \\
\hline Guadeloupe & II & II & ----- \\
\hline Haiti & III & III & ----- \\
\hline Jamaica & II & II & ----- \\
\hline Martinique & II & II & ----- \\
\hline Netherlands Antilles & 1 & I & ----- \\
\hline Puerto Rico & II & II & ---- \\
\hline Saint Lucia & II & II & ----- \\
\hline Saint Vincent and the Grenadines & IV & III & Coale-Demeny West \\
\hline Trinidad and Tobago & III & III & ----- \\
\hline United States Virgin Islands & III & III & UN Far East \\
\hline \multicolumn{4}{|l|}{ Central America } \\
\hline Belize & IV & IV & UN General \\
\hline Costa Rica & II & II & ----- \\
\hline El Salvador & II & II & ----- \\
\hline Guatemala & II & II & ----- \\
\hline Honduras & II & II & ----- \\
\hline Mexico & II & II & ----- \\
\hline Nicaragua & II & II & ----- \\
\hline Panama & II & II & ----- \\
\hline \multicolumn{4}{|l|}{ South America } \\
\hline Argentina & I & I & ---- \\
\hline Bolivia & III & III & ----- \\
\hline Brazil & II & II & ----- \\
\hline Chile & 1 & I & ----- \\
\hline Colombia & II & II & ---- \\
\hline Ecuador & ॥ & II & ---- \\
\hline French Guiana & III & III & Coale-Demeny West \\
\hline Guyana & III & III & ----- \\
\hline Paraguay & II & II & ----- \\
\hline Peru & II & II & ----- \\
\hline
\end{tabular}




\begin{tabular}{lccc}
\hline & 2004 & 2006 & Model Life Table System \\
\hline Suriname & II & II & ----- \\
Uruguay & II & II & ---- \\
Venezuela & II & II & ---- \\
Northern America & & & \\
$\quad$ Canada & I & I & ---- \\
United States of America & I & I & ---- \\
Oceania & & & \\
Australia/New Zealand & & & \\
Australia & I & I & ----- \\
New Zealand & I & I & ---- \\
Melanesia & & & \\
$\quad$ Fiji & III & III & UN Far East \\
New Caledonia & III & III & Coale-Demeny West \\
Papua New Guinea & III & III & UN Far East \\
Solomon Islands & III & III & Coale-Demeny West \\
Vanuatu & III & III & UN Far East \\
Micronesia & & & \\
$\quad$ Guam & III & III & ----- \\
Micronesia (Federated States of) & IV & IV & Coale-Demeny West \\
Polynesia & & & \\
French Polynesia & II & II & ----- \\
Samoa & III & III & UN Far East \\
Tonga & III & III & UN Far East \\
\hline & & & \\
\hline
\end{tabular}

Note: ----- not applicable

Source: own reconstruction based on information provided by the United Nations (2006, 2008) and Lopez et al. (2006). 


\section{Comparative Population Studies - Zeitschrift für Bevölkerungswissenschaft}

wWw.comparativepopulationstudies.de

ISSN: 1869-8980 (Print) - 1869-8999 (Internet)

Published by / Herausgegeben von

Prof. Dr. Norbert F. Schneider

Layout and print: Federal Institute for Population Research, Wiesbaden

(Germany)

\section{Managing Editor / Redaktion}

Frank Swiaczny

Copy Editor / Schlußredaktion

Dr. Evelyn Grünheid

\section{Scientific Advisory Board / \\ Wissenschaftlicher Beirat}

Jürgen Dorbritz (Wiesbaden)

Paul Gans (Mannheim)

Johannes Huinink (Bremen)

Dirk J. van de Kaa (Den Haag)

Marc Luy (Wien)

Notburga Ott (Bochum)

Peter Preisendörfer (Mainz)

\section{Board of Reviewers / Gutachterbeirat}

Martin Abraham (Erlangen)

Laura Bernardi (Lausanne)

Hansjörg Bucher (Bonn)

Claudia Diehl (Göttingen)

Andreas Diekmann (Zürich)

Gabriele Doblhammer-Reiter (Rostock)

Henriette Engelhardt-Wölfler (Bamberg)

E.-Jürgen Flöthmann (Bielefeld)

Alexia Fürnkranz-Prskawetz (Wien)

Beat Fux (Zürich)

Joshua Goldstein (Rostock)

Karsten Hank (Mannheim)

Sonja Haug (Regensburg)

Franz-Josef Kemper (Berlin)

Hans-Peter Kohler (Philadelphia)

Michaela Kreyenfeld (Rostock)

Aart C. Liefbroer (Den Haag)

Kurt Lüscher (Konstanz)

Dimiter Philipov (Wien)

Tomáš Sobotka (Wien)

Heike Trappe (Rostock) 